\title{
KARAKTERISTIK EKSTRAK ASBUTON EMULSI MENGGUNAKAN PEREMAJA SOLAR YANG DIMODIFIKASI DENGAN ASPAL PENETRASI 60/70 (SEMARBUT ASPAL TIPE 4)
}

\author{
Djoko Sarwono $^{1)}$, Suryoto $^{2)}$, Dian Putri Rahmawati ${ }^{3)}$ \\ 1) 2) 3) Roadmate Research Group, Teknik Sipil, Universitas Sebelas Maret \\ Roadmate Research Group, Laboratorium Jalan Raya, Fakultas Teknik, Universitas Sebelas Maret \\ e-mail : ${ }^{1}$ sarwono60@yahoo.co.id ${ }^{2}$ suryo to91@yaohoo.com ${ }^{3)}$ dprahmawati5@gmail.com
}

\begin{abstract}
Research on the extraction of asbuton by emulsion method using oil as rejuvenator already done still found several obstacles, namely the time of mixing asbuton and kerosene is very long led to increasingly mineral content lots and bitumen are produced using premium is very brittle. To improve the characteristics of asbuton then extract added bitumen 60/70 and substituting rejuvenator. On the research of rejuvenator materials used is diesel oil, because it has a high viscosity value and is heavy oil, so that the resulting bitumen is not brittle. Next ekatrak asbuton modified with bitumen 60/70 be Asphalt Semarbut Type 4. A review that is used is the time mixing asbuton and diesel oil to obtain optimum levels of solubility of asphalt and composition variation of Asphalt Semarbut type 4 to obtain the optimum composition of the semarbut. Results of testing the levels of solubility of asphalt mixing time obtained asbuton and solar for 2 minutes 50 seconds produces the optimum levels of solubility of bitumen of $86.62 \%$. The value of the resulting extract daktilitas asbuton too small, so to fix it added bitumen 60/70 be Asphalt Semarbut Type 4. The results of testing characteristics of asphalt modification obtained the best composition i.e. 40\% asbuton extract and $60 \%$ bitumen $60 / 70$, with characteristics test results i.e penetration value is $45,7 \mathrm{dmm}$; its softening point is $55,5^{\circ} \mathrm{C}$; its flash point is $242^{\circ} \mathrm{C}$; its burns point is $279^{\circ} \mathrm{C}$; its ductility value is $54,75 \mathrm{~cm}$; its specific gravity is $1,2304 \mathrm{gr} / \mathrm{cm} 3$ and its stickiness is $100 \%$.
\end{abstract}

Keywords : Mixing, Characteristic, Optimum

\begin{abstract}
Abstrak
Penelitian ekstraksi asbuton dengan metode emulsi menggunakan peremaja minyak yang sudah dilakukan masih ditemukan beberapa kendala, yaitu waktu pencampuran asbuton dan peremaja kerosin lama menyebabkan kandungan mineral banyak dan aspal yang dihasilkan dengan menggunakan peremaja premium getas. Untuk memperbaiki karakteristik ekstrak asbuton maka ditambahkan aspal penetrasi 60/70 dan mengganti peremaja. Penelitian ini peremaja yang digunakan adalah solar, karena memiliki nilai viskositas yang tinggi dan merupakan minyak berat, sehingga aspal yang dihasilkan tidak getas. Selanjutnya ekatrak asbuton dimodifikasi dengan aspal penetrasi 60/70 menjadi Semarbut Aspal Tipe 4. Tinjauan yang digunakan adalah waktu mixing asbuton dan solar untuk memperoleh kadar kelarutan ekstrak asbuton optimum dan variasi komposisi dari Semarbut Aspal Tipe 4 untuk memperoleh komposisi optimum semarbut. Hasil pengujian kadar kelarutan ekstrak asbuton diperoleh waktu mixing asbuton dan solar 2 menit 50 detik menghasilkan kadar kelarutan optimum sebesar 86,62\%. Nilai daktilitas ekstrak asbuton yang dihasilkan terlalu kecil, sehingga untuk memperbaikinya ditambahkan aspal penetrasi 60/70 menjadi Semarbut Aspal Tipe 4. Hasil pengujian karakteristik Semarbut Aspal Tipe 4 diperoleh komposisi optimum yaitu kadar ekstrak asbuton sebesar 40\% dan kadar aspal penetrasi $60 / 70$ sebesar $60 \%$, dengan hasil uji karakteristik yaitu nilai penetrasi $45,7 \mathrm{dmm}$; titik lembek $55,5{ }^{\circ} \mathrm{C}$; titik nyala $242{ }^{\circ} \mathrm{C}$; titik bakar $279{ }^{\circ} \mathrm{C}$; daktilitas $54,75 \mathrm{~cm}$; berat jenis 1,2304 gr/cc dan kelekatan 100\%.
\end{abstract}

Kata Kunci : Mixing, Karakteristik, Optimum

\section{PENDAHULUAN}

Penelitian mengenai ekstraksi asbuton dengan metode emulsi menggunakan bahan peremaja kerosin dan premium yang sudah dilakukan masih ditemukan beberapa kendala. Kendala yang terjadi pada ekstraksi asbuton menggunakan metode emulsi dengan bahan peremaja kerosin adalah waktu pencampuran asbuton dan kerosin yang sangat lama (25 menit) menyebabkan kandungan mineral dalam hasil ekstraksi asbuton semakin banyak sehingga mengurangi nilai optimum yang dicapai. Sedangkan kendala yang terjadi pada ekstraksi asbuton dengan metode emulsi menggunakan bahan peremaja premium adalah aspal yang dihasilkan sangat getas, hal ini dapat dilihat dari nilai daktilitas dan penetrasi yang tidak dapat terukur (nilainya 0 ).

Untuk memperbaiki nilai karakteristik hasil ekstraksi asbuton, maka ditambahkan aspal penetrasi 60/70 (Semarbut Aspal). Semarbut Aspal Tipe 1 adalah penelitian tentang modifikasi aspal penetrasi 60/70 dengan ekstrak asbuton menggunakan bahan peremaja kerosin yang dilakukan oleh Sadu Januar (2014). kadar optimum ekstrak asbuton pada Semarbut Aspal Tipe 1 adalah 27,5\%, akan tetapi hasil uji penetrasi terlalu tinggi sehingga aspal yang dihasilkan sangat lembek. Semarbut Aspal Tipe 2 adalah penelitian tentang modifikasi aspal penetrasi 60/70 dengan ekstrak asbuton menggunakan bahan peremaja premium yang dilakukan oleh Luqman Try (2016) dan menghasilkan kadar optimum ekstrak asbuton pada semarbut sebesar 42,5\%. 
Penelitian ini merupakan lanjutan dari penelitian semarbut yang menggunakan solar sebagai bahan peremaja saat proses pembuatan ekstrak asbuton emulsi. Pemilihan bahan peremaja solar karena solar memiliki nilai viskositas yang tinggi dan merupakan salah satu jenis minyak berat, sehingga dengan menggunakan bahan peremaja solar diharapkan aspal yang dihasilkan tidak getas. Selanjutnya ekstrak asbuton dimodifikasi menggunakan aspal penetrasi 60/70 menjadi Semarbut Aspal Tipe 4. Modifikasi aspal pada penelitian ini bertujuan menghasilkan kadar optimum ekstrak asbuton pada komposisi semarbut yang lebih besar sehingga dapat mengurangi penggunaan aspal minyak.

\section{LANDASAN TEORI}

Penelitian tentang "Kinerja Properti SEMARBUT Aspal Tipe I (Penambahan Ekstraksi Asbuton Emulsi sebagai Modifikasi Bitumen)" Sadu Januar tahun 2014 diperoleh hasil penambahan maksimum ekstraksi asbuton emulsi sebesar 27,5\% terhadap aspal penetrasi 60/70 dengan nilai uji karakteristik aspal yaitu nilai penetrasi 11,07 mm, daktilitas $100,5 \mathrm{~cm}$, titik lembek $48,5^{\circ} \mathrm{C}$, titik nyala dan titik bakar sekitar $200^{\circ} \mathrm{C}$, berat jenis $1,076 \mathrm{gr} / \mathrm{cc}$ dan kelekatan $100 \%$.

Penelitian tentang "Pengarub Waktu Pemeraman Asbuton dalam Ekstraksi Asbuton Menggunakan Premium dan Emulgator Texapon dengan Alat Grinder Tipe MB 60" oleh Rifqi Surya Darendra pada tahun 2016 diperoleh waktu pemeraman fase padat paling optimum selama 120 menit menghasilkan kadar kelarutan aspal hasil ekstraksi asbuton sebesar $94,77 \%$. Nilai karakteristik hasil ekstraksi asbuton yaitu titik lembek $>100^{\circ} \mathrm{C}$; titik nyala dan titik bakar 270 dan $290^{\circ} \mathrm{C}$; berat jenis $1,66 \mathrm{gr} / \mathrm{cc}$ serta kelekatan terhadap agregat $100 \%$. Aspal yang dihasilkan pada penilitian ini keras dan kaku, sehingga belum dapat terukur nilai penetrasi dan daktilitasnya.

Penelitian tentang "Karakteristik Penambahan Ekstraksi Asbuton Emulsi pada Aspal Penetrasi 60/70 Sebagai Modifikasi Bitumen (Semarbut Aspal Tipe 2)" oleh Luqman Tri Wibowo pada tahun 2016 diperoleh hasil penambahan optimum ekstrak asbuton yang memenuhi spesifikasi aspal penetrasi 60/70 menurut SNI 06-2456-1991 adalah 42,5\%. Hasil pengujian karakteristik Semarbut Aspal Tipe 2 yaitu penetrasi $51 \times 10^{-1} \mathrm{~mm}$; daktilitas $112,5 \mathrm{~cm}$; titik lembek $48-58^{\circ} \mathrm{C}$; titik nyala dan titik bakar diatas $200^{\circ} \mathrm{C}$; berat jenis diatas 1,00 gr/cc serta kelekatan terhadap agregat $100 \%$.

\section{Asbuton Butir}

Asbuton butir yang dicampur dengan bahan emulsifier, asam klorida $(\mathrm{HCl})$, bahan peremaja dan aquades $\left(\mathrm{H}_{2} \mathrm{O}\right)$ menggunakan alat mixer dan menghasilkan campuran dingin disebut sebagai asbuton emulsi. Bahan pengemulsi yang digunakan pada campuran asbuton butir berfungsi untuk mendispersikan partikel-partikel aspal dalam air. Kandungan aspal pada asbuton akan diikat oleh bagian polar emulsifier dan selanjutnya diekstraksi sehingga didapatkan produk asbuton dengan kadar filler yang lebih rendah dari sebelumnya. Produk asbuton yang memiliki kadar filler rendah diharapkan dapat meningkatkan workability asbuton sebagai bahan utama konstruksi perkerasan jalan.

\section{Ekstraksi Asbuton}

Ekstraksi adalah suatu metode yang digunakan untuk memindahkan senyawa dari suatu padatan atau cairan ke cairan lain yang berfungsi sebagai peremaja. Untuk memisahkan zat terlarut (terdispersi) yang diinginkan, maka harus dicampurkan dengan zat pelarut (pendispersi). Pada proses pencampuran padat-cair atau leaching, terjadi transfer difusi komponen terlarut (aspal asbuton) dari padatan inert (batuan asbuton) kedalam peremaja. Saat proses leaching asbuton, dilakukan penghancuran dan penggilingan batuan asbuton sesuai ukuran tertentu sebelum ekstraksi untuk meningkatkan laju leaching, hal tersebut dilakukan agar peremaja lebih mudah berdifusi. Hasil ekstraksi halus adalah asbuton emulsi yang diekstraksi dan lolos saringan nomer 40, sedangkan hasil ekstraksi kasar adalah asbuton emulsi yang diekstraksi dan tidak lolos saringan nomer 40. Pada penelitian ini digunakan hasil ekstraksi halus dari asbuton emulsi (ekstrak asbuton) karena kandungan aspal didalamnya lebih banyak daripada hasil ekstraksi kasar asbuton emulsi.

\section{Semarbut Aspal}

Semarbut Aspal adalah aspal yang dimodifikasi dengan hasil ekstraksi asbuton. Semarbut merupakan kepanjangan dari sebelas maret (semar) asbuton, diberi nama sebelas maret karena penelitiannya dilakukan di Universitas Sebelas Maret Surakarta. Hingga saat ini semarbut aspal sudah memiliki dua tipe, yang membedakan 
dari setiap tipe adalah bahan peremaja yang digunakan saat ekstraksi asbuton dan komposisi dari semarbut yang dijelaskan sebagai berikut:

- Semarbut aspal tipe 1 menggunakan kerosin sebagai peremaja dan komposisi yang digunakan adalah ekstrak asbuton sebesar $27,5 \%$ dan apal penetrasi $60 / 70$ sebesar $72,5 \%$,

- Semarbut aspal tipe 2 menggunakan premium sebagai peremaja dan komposisi yang digunakan adalah ekstrak asbuton sebesar $42,5 \%$ dan apal penetrasi $60 / 70$ sebesar $57,5 \%$,

\section{METODE PENELITIAN}

Pembuatan ekstrak asbuton menggunakan metode asbuton emulsi dan komposisi bahan untuk membuat asbuton emulsi dapat dilihat pada Tabel 1. Bahan-bahan yang digunakan untuk membuat asbuton emulsi pada penelitian ini adalah asbuton butir tipe 5/20, solar, aquades, $\mathrm{HCl}$ dan texapon. Sebelum semua bahan dicampur, asbuton dan bahan peremaja (solar) diperam terlebih dahulu selama 2 jam kemudian di mixing dengan variasi waktu 2, 3, 4, 5 dan 6 menit. Selanjutnya asbuton dan solar dicampur dengan asam klorida dan texapon yang sudah dilarutkan dalam aquades (proses asbuton emulsi). Untuk memisahkan mineral dan aspal yang ada di dalam asbuton, maka asbuton emulsi diekstraksi dengan kecepatan 2000 rpm selama $2 \times 25$ menit. Proses ekstraksi asbuton menghasilkan dua hasil, yaitu hasil ekstraksi halus dan kasar. Hasil ekstraksi halus adalah asbuton emulsi yang diekstraksi dan lolos saringan nomer 40, sedangkan hasil ekstraksi kasar adalah asbuton emulsi yang diekstraksi dan tidak lolos saringan nomer 40. Pada penelitian ini, ekstrak asbuton yang digunakan adalah hasil ekstraksi halus dari asbuton emulsi karena kandungan aspal didalamnya lebih banyak dan kandungan mineral lebih sedikit daripada hasil ekstraksi kasar asbuton emulsi.

Tabel 1. Komposisi ekstrak asbuton dengan metode asbuton emulsi menggunakan bahan peremaja solar

\begin{tabular}{lllll}
\hline $\begin{array}{l}\text { Asbuton } \\
\text { (gr) }\end{array}$ & $\begin{array}{l}\text { Solar } \\
\text { (gr) }\end{array}$ & $\begin{array}{l}\text { Texapon } \\
\text { (gr) }\end{array}$ & $\begin{array}{l}\text { HCl } \\
\text { (gr) }\end{array}$ & $\begin{array}{l}\text { Aquades } \\
\text { (gr) }\end{array}$ \\
\hline 400 & 80 & 4 & 4,81 & 200 \\
\hline
\end{tabular}

Pembuatan Semarbut Aspal Tipe 4 menggunakan metode pencampuran panas-panas, yaitu memanaskan aspal penetrasi $60 / 70$ hingga $100^{\circ} \mathrm{C}$ terlebih dahulu kemudian dicampur dengan ekstrak asbuton yang sudah dipanaskan sehingga kandungan air didalamnya hilang. Pada tahap ini dilakukan beberapa variasi komposisi antara kadar asbuton emulsi dan kadar aspal penetrasi 60/70 yang dapat dilihat pada Tabel 2.

Tabel 2. Variasi komposisi Semarbut Aspal Tipe 4

\begin{tabular}{lll}
\hline No & Kadar ekstrak asbuton (\%) & Kadar aspal penetrasi $\mathbf{6 0 / 7 0}(\%)$ \\
\hline 1. & 35,0 & 65,0 \\
\hline 2. & 37,5 & 62,5 \\
\hline 3. & 40,0 & 60,0 \\
\hline 4. & 42,5 & 57,5 \\
\hline 5. & 45,0 & 55,0 \\
\hline
\end{tabular}

Pengujian yang dilakukan pada penelitian ini meliputi kadar kelarutan aspal dari ekstrak asbuton serta pengujian karakteristik ekstrak asbuton dengan kadar kelarutan aspal optimum dan pengujian karakteristik campuran aspal penetrasi 60/70 dengan hasil ekstraksi asbuton (Semarbut Aspal Tipe 4). Pengujian karakteristik aspal diantaranya adalah uji penetrasi, titik nyala, titik bakar, titik lembek, daktilitas, berat jenis dan kelekatan emulsi hasil ekstraksi.

\section{HASIL DAN PEMBAHASAN}

\section{Hasil Pengujian Kadar Kelarutan Aspal Ekstrak Asbuton}

Uji kadar kelarutan aspal ekstrak asbuton merupakan pengujian yang digunakan untuk mengetahui presentase kadar aspal dari ekstrak asbuton yang dapat larut dalam Trichloroetbylene (TCE). Uji kelarutan ini mengacu pada pedoman SNI 2438-2015 yaitu tentang cara uji kelarutan aspal. Pengujian ini dilakukan setelah kandungan air pada proses emulsi yang ada didalam ekstrak asbuton menghilang. Rekapitulasi perhitungan kadar kelarutan aspal hasil ekstraksi asbuton dengan bahan peremaja solar disajikan pada Tabel 3 dan grafik regresi polynomial 
hubungan waktu mixing asbuton dan solar terhadap kadar kelarutan aspal ekstrak asbuton dapat dilihat pada Gambar 1.

Tabel 3. Rekapitulasi hasil pengujian kadar kelarutan aspal ekstrak asbuton

\begin{tabular}{llllll}
\hline \multirow{2}{*}{$\begin{array}{l}\text { Kode } \\
\text { Uampel }\end{array}$} & \multicolumn{5}{l}{ Variasi waktu } \\
\cline { 2 - 6 } & $\mathbf{2}$ menit & $\mathbf{3}$ menit & $\mathbf{4}$ menit & $\mathbf{5}$ menit & $\mathbf{6}$ menit \\
\cline { 2 - 6 } & $\mathbf{( \% )}$ & $\mathbf{( \% )}$ & $\mathbf{( \% )}$ & $\mathbf{( \% )}$ & $\mathbf{( \% )}$ \\
\hline S-A & 85,02 & 87,84 & 84,23 & 82,69 & 75,77 \\
\hline S-B & 85,13 & 88,94 & 86,47 & 83,90 & 80,91 \\
\hline S-C & 85,15 & 89,17 & 83,41 & 77,83 & 78,67 \\
\hline Rata-rata & 85,10 & 88,65 & 84,71 & 81,47 & 78,45 \\
\hline
\end{tabular}

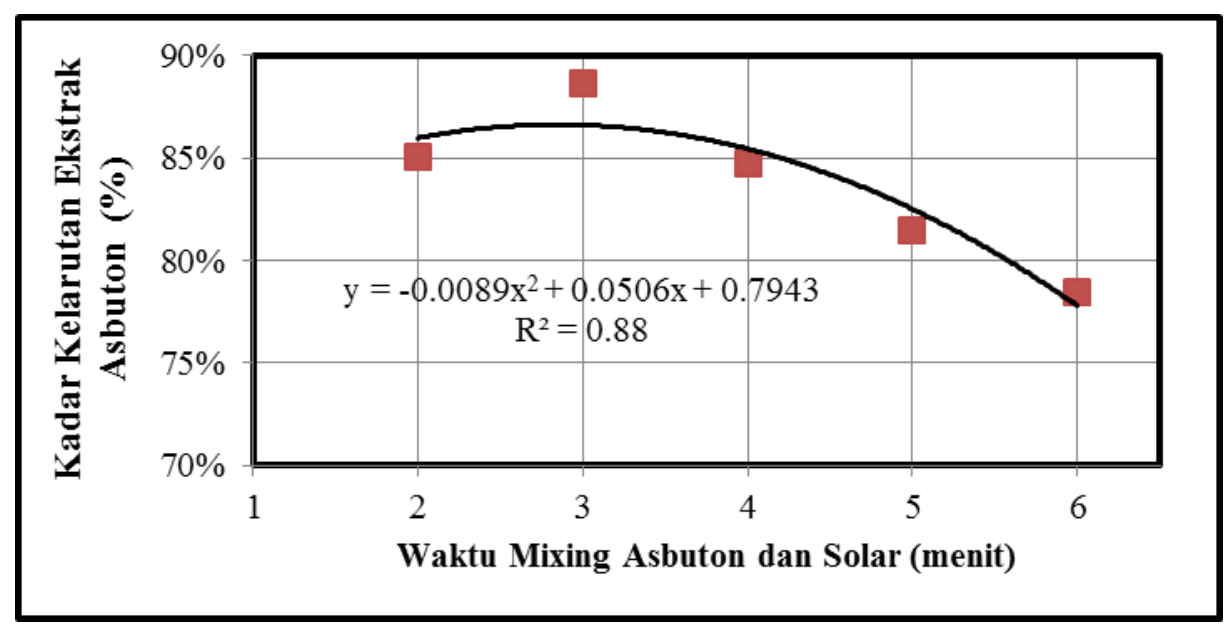

Gambar 1. Rekapitulasi hasil pengujian kadar kelarutan aspal ekstrak asbuton

Gambar 1 menunjukkan bahwa bertambahnya waktu mixing asbuton dan solar meningkatkan kadar aspal hasil ekstraksi asbuton hingga kurun waktu tertentu (waktu optimum) dan akan kembali menurun setelahnya. Semakin lama waktu mixing asbuton dan solar dengan bahan peremaja (solar) akan semakin banyak mengikat kandungan aspal yang terdapat dalam asbuton butir, namun jika waktu mixing asbuton dan solar ditambah, mineral asbuton butir akan semakin halus dan juga akan semakin banyak yang terikat oleh bahan peremaja sehingga ekstrak halus yang dihasilkan akan mengandung banyak filler. Waktu mixing asbuton dan solar yang menghasilkan presentase kelarutan ekstrak asbuton tertinggi dapat diketahuai dengan cara mensubtitusikan x (waktu mixing asbuton dan solar) pada persamaan $\mathrm{y}=-0,0089 \mathrm{x}^{2}+0,0506 \mathrm{x}+0,7943$ dan diperoleh waktu mixing asbuton dan solar optimum pada 2 menit 50 detik dengan y sebesar $86,62 \%$.

\section{Hasil Uji Karakteristik Aspal Hasil Ekstraksi Asbuton}

Pengujian ini dilakukan pada ekstrak asbuton dengan kadar aspal optimum yang dipanaskan hingga mengalami kehilangan berat sebesar $\pm 33 \%$ dari berat awal, hal ini bertujuan untuk mempercepat menghilangkan kandungan air dan sedikit kandungan solar pada saat proses emulsi. Hasil uji karakteristik aspal ekstrak asbuton dapat dilihat pada Tabel 4.

Tabel 4. Rekapitulasi Hasil Pengujian Karakteristik Ekstrak Asbuton

\begin{tabular}{llll}
\hline Nama pengujian & Pedoman pengujian & Nilai uji & Satuan \\
\hline Penetrasi & RSNI 06-2456-1991 & 52 & $0,1 \mathrm{~mm}$ \\
\hline Titik lembek & RSNI 06-2434-1991 & 77,5 & $\mathrm{O} C$ \\
\hline Titik nyala dan bakar & SNI 06-2433-1991 & 231 dan 240 & $\mathrm{O}$ \\
\hline Daktilitas & SNI 06-2432-1991 & 7 & $\mathrm{Cm}$ \\
\hline Berat jenis & SNI 06-2441-1991 & 1,595 & $\mathrm{gr} / \mathrm{cc}$ \\
\hline Kelekatan & PA-0312-76 & 100 & $\%$ \\
\hline Kelarutan dalam tce & RSNI M-04-2004 & 88,62 & $\%$ \\
\hline
\end{tabular}


Hasil uji karakteristik ekstrak asbuton mengunakan bahan peremaja solar untuk nilai titik lembek, titik nyala dan bakar, kelekatan sudah memenuhi spesifikasi aspal pada umumnya, sedangkan untuk nilai daktilitas masih terlalu kecil dan nilai penetrasi terlalu besar. Maka untuk meningkatkan nilai karakteristik dari ekstraksi asbuton ditambahkan aspal penetrasi 60/70 dengan kadar tertentu, sehingga nilai karakteristik aspal sesuai dengan persyaratan dan dapat digunakan dalam pekerjaan konstruksi jalan.

\section{Hasil Uji Karakteristik Semarbut Aspal Tipe 4}

Sampel yang diuji karakteristik adalah modifikasi aspal penetrasi 60/70 dengan kadar ekstrak asbuton 35\%; 37,5\%; 40\%; 42,5\% dan 45\% dan hasil dari pengujian dapat dilihat pada Tabel 5.

Tabel 5. Rekapitulasi hasil pengujian karakteristik variasi komposisi Semarbut Aspal Tipe 4

\begin{tabular}{|c|c|c|c|c|c|c|c|c|}
\hline \multirow{3}{*}{$\begin{array}{l}\text { Kadar } \\
\text { ekstrak } \\
\text { asbuton } \\
(\%)\end{array}$} & \multirow{3}{*}{$\begin{array}{l}\text { Kadar } \\
\text { aspal pen } \\
60 / 70 \\
(\%)\end{array}$} & \multicolumn{7}{|c|}{ Hasil pengujian karakteristik } \\
\hline & & Penetrasi & $\begin{array}{l}\text { Titik } \\
\text { lembek }\end{array}$ & $\begin{array}{l}\text { Titik } \\
\text { nyala }\end{array}$ & $\begin{array}{l}\text { Titik } \\
\text { bakar }\end{array}$ & Daktilitas & $\begin{array}{l}\text { Berat } \\
\text { jenis }\end{array}$ & Kelekatan \\
\hline & & $\left(\times 10^{-1} \mathrm{~mm}\right)$ & $\left({ }^{\circ} \mathrm{C}\right)$ & $\left({ }^{\circ} \mathbf{C}\right)$ & $\left({ }^{\circ} \mathrm{C}\right)$ & $(\mathrm{cm})$ & (gr/cc) & $(\%)$ \\
\hline 35,0 & 65,0 & 51,6 & 55,75 & 240 & 283 & 59,75 & 1,1980 & 100 \\
\hline 37,5 & 62,5 & 46,7 & 54,75 & 241 & 281 & 57,50 & 1,2113 & 100 \\
\hline 40,0 & 60,0 & 45,7 & 55,50 & 242 & 279 & 54,75 & 1,2304 & 100 \\
\hline 42,5 & 57,5 & 43,1 & 55,75 & 237 & 270 & 48,00 & 1,2350 & 100 \\
\hline 45,0 & 55,0 & 37,7 & 56,50 & 236 & 261 & 47,00 & 1,2421 & 100 \\
\hline
\end{tabular}

Hasil Uji Penetrasi

Hasil pengujian penetrasi dari semua variasi komposisi Semarbut Aspal Tipe 4 dapat dilihat pada Gambar 2.

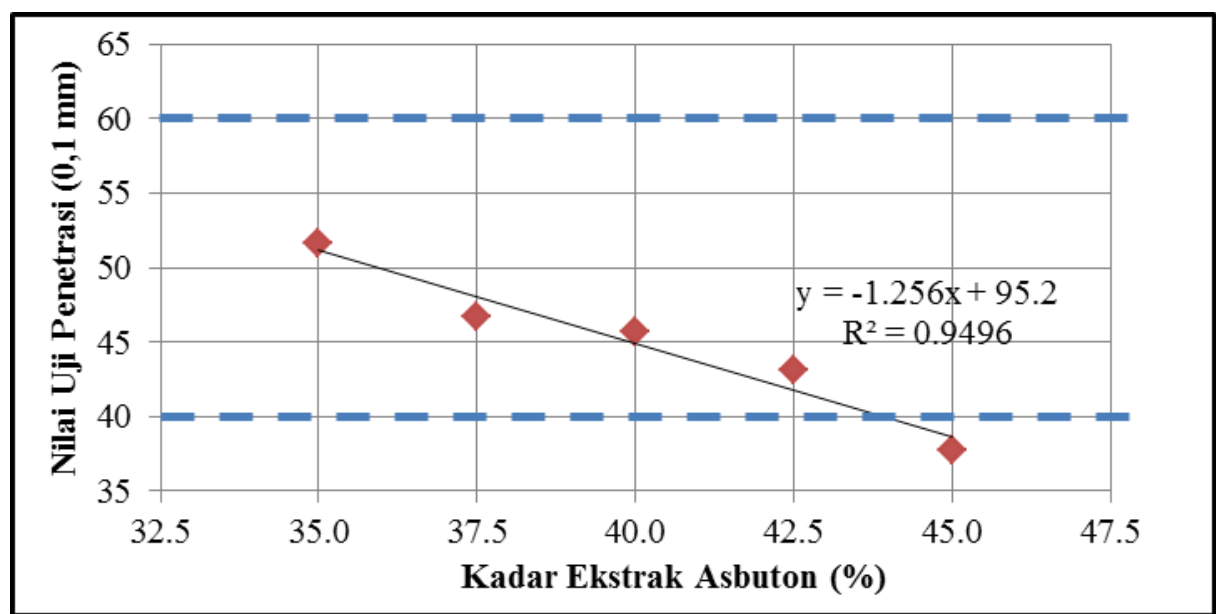

Persyaratan $=40-60 \times 10^{-1} \mathrm{~mm}$, Sumber : Pedoman Konstruksi dan Bangunan, No: 00101/BM/2006, Pemanfaatan Asbuton, Departemen Pekerjaan Umum Ditjen Bina Marga

Gambar 2. Grafik hasil uji penetrasi variasi Semarbut Aspal Tipe 4

Gambar 2 menunjukkan bahwa penambahan kadar ekstrak asbuton pada Semarbut Aspal Tipe 4 membuat nilai penetrasi semakin turun, sesuai fungsi dari grafik yaitu $y=-1,256 x+95,2$ bahwa penambahan kadar ekstrak asbuton berkorelasi negatif dengan nilai penetrasi. Semakin banyak kadar ekstrak asbuton yang ditambahkan semakin rendah nilai penetrasi yang dihasilkan sehingga aspal semakin keras, hal ini dipengaruhi oleh kandungan filler yang ada didalam ekstrak asbuton yang membuat campuran aspal menjadi semakin keras. Nilai penetrasi penambahan kadar ekstrak asbuton sebesr $45 \%$ tidak memenuhi persyaratan tersebut karena nilai penetrasi yang dihasilkan kurang dari $40 \mathrm{dmm}$. 
Hasil Uji Titik Lembek

Hasil pengujian titik lembek dari semua variasi komposisi Semarbut Aspal Tipe 4 dapat dilihat pada Gambar 3.

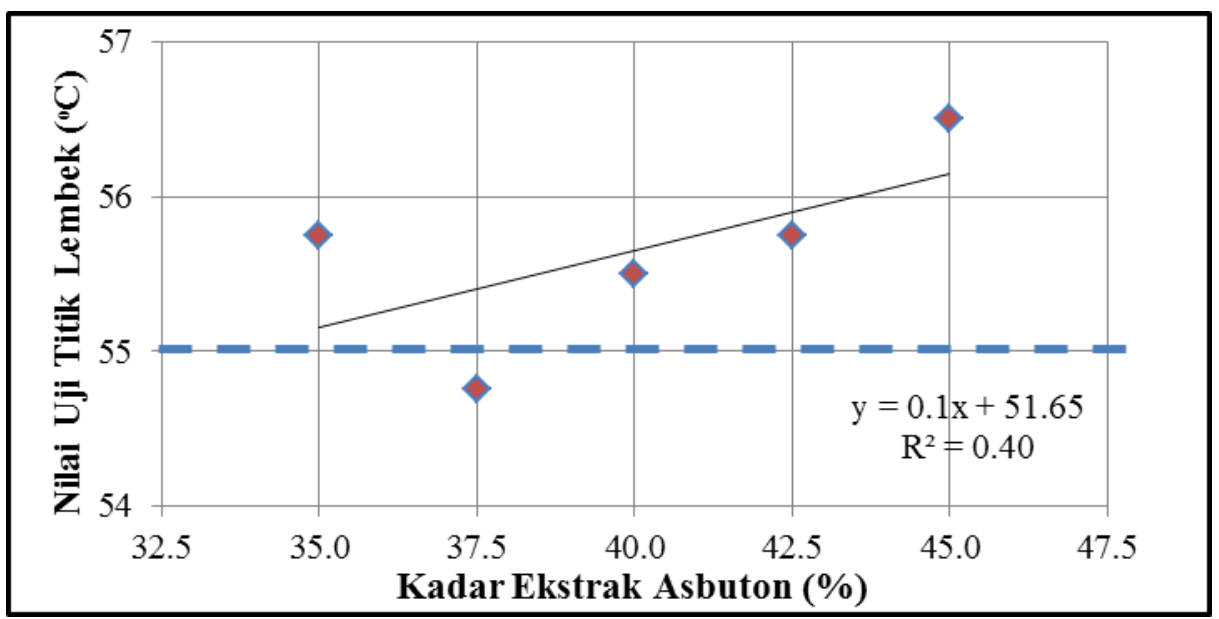

Persyaratan $=55{ }^{\circ} \mathrm{C}$, Sumber : Pedoman Konstruksi dan Bangunan, No: 001-01/BM/2006, Pemanfaatan Asbuton, Departemen Pekerjaan Umum, Direktorat Jendral Bina Marga

Gambar 3. Grafik hasil uji titik lembek variasi Semarbut Aspal Tipe 4

Gambar 3 menunjukkan bahwa semakin banyak kadar ekstrak asbuton yang ditambahkan semakin tinggi nilai titik lembek yang dihasilkan dan suhu titik lembek yang tinggi menunjukkan bahwa semarbut aspal kurang peka terhadap perubahan temperatur sekitar, sehingga baik digunakan sebagai bahan pengikat. Penambahan kadar ekstrak asbuton sebesar 37,5\% tidak memenuhi spesifikasi karena suhu yang diperoleh kurang dari $55{ }^{\circ} \mathrm{C}$.

Hasil Uji Titik Nyala dan Titik Bakar

Hasil pengujian titik nyala dan titik bakar dari semua variasi komposisi Semarbut Aspal Tipe 4 dapat dilihat pada Gambar 4.

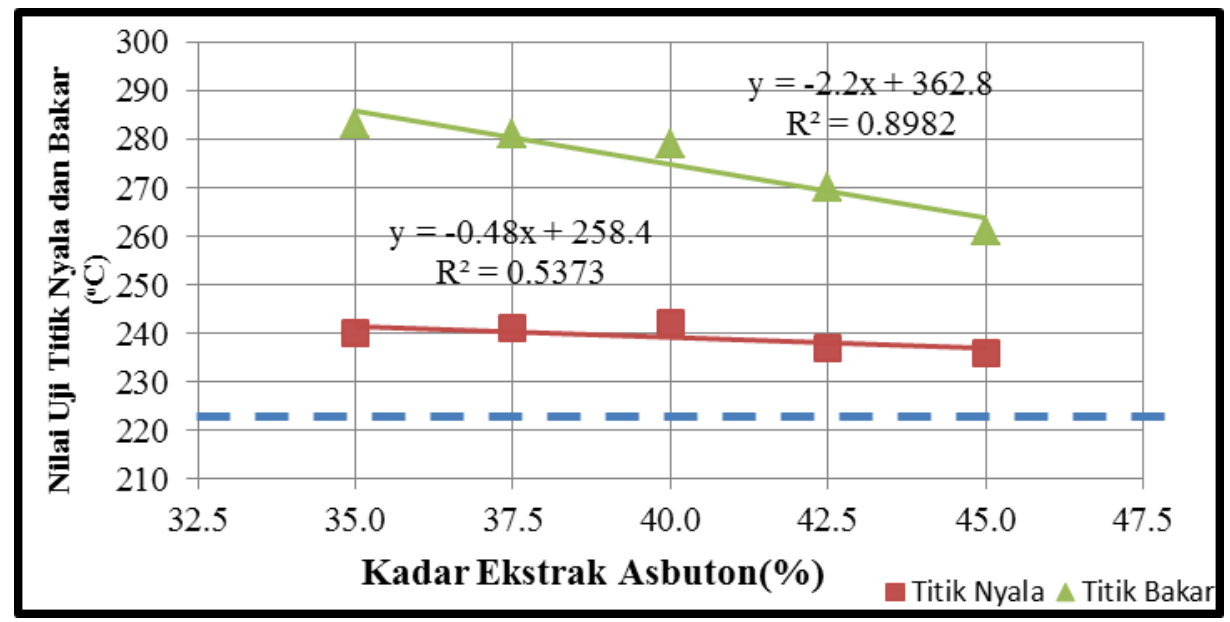

Persyaratan $=225{ }^{\circ} \mathrm{C}$, Sumber : Pedoman Konstruksi dan Bangunan, No: 001-01/BM/2006, Pemanfaatan Asbuton, Departemen Pekerjaan Umum, Direktorat Jendral Bina Marga

Gambar 4. Grafik hasil uji titik nyala dan titik bakar variasi Semarbut Aspal Tipe 4 
Gambar 4 menunjukkan bahwa semakin banyak kadar ekstrak asbuton yang ditambahkan semakin rendah nilai titik nyala dan titik bakar yang dihasilkan. Suhu titik nyala dan titik bakar dari kelima variasi memenuhi syarat spesifikasi aspal yang dimodifikasi dengan asbuton yaitu suhu minimal $225^{\circ} \mathrm{C}$. Penurunan suhu pada titik nyala dan titik bakar dikarenakan masih adanya kadar solar dalam ekstrak asbuton yang mana proses peremajaanya diperkirakan belum selesai.

Hasil Uji Daktilitas

Hasil pengujian daktilitas dari semua variasi komposisi Semarbut Aspal Tipe 4 dapat dilihat pada Gambar 5.

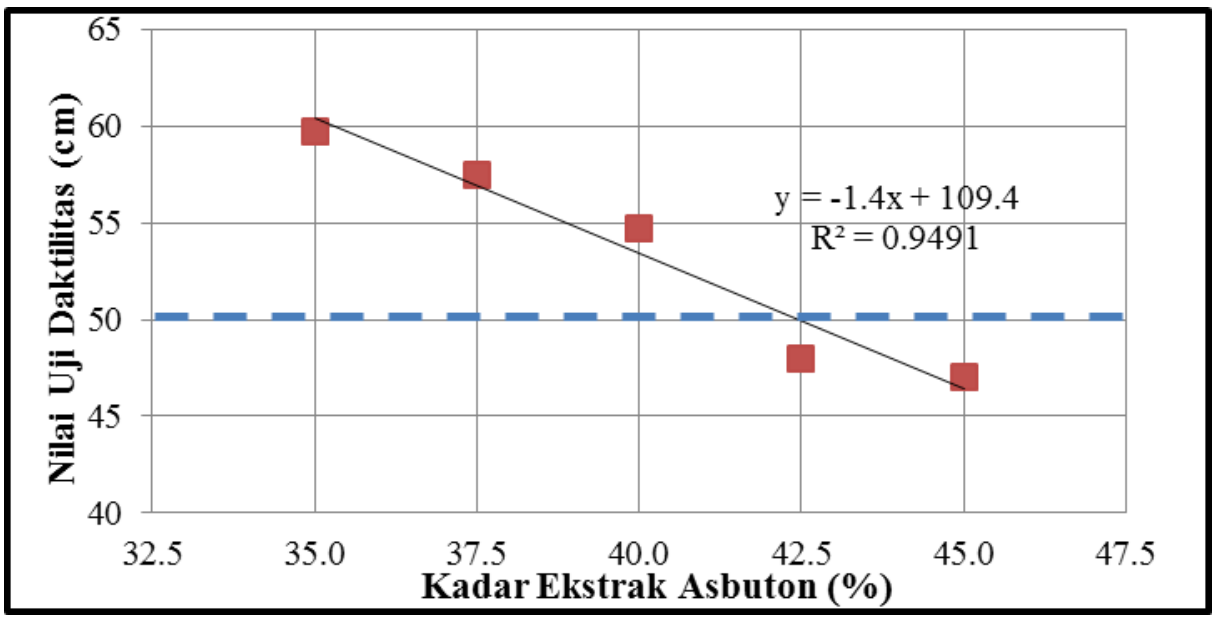

Persyaratan $=50 \mathrm{~cm}$, Sumber : Pedoman Konstruksi dan Bangunan, No: 001-01/BM/2006, Pemanfaatan Asbuton, Departemen Pekerjaan Umum, Direktorat Jendral Bina Marga

Gambar 5. Grafik hasil uji daktilitas variasi Semarbut Aspal Tipe 4

Gambar 5 menunjukkan bahwa penambahan kadar ekstrak asbuton pada Semarbut Aspal Tipe 4 membuat nilai uji daktilitas semakin turun. Grafik di atas menunjukkan penambahan kadar ekstrak asbuton sebesar $42,5 \%$ dan $45 \%$ tidak memenuhi persyaratan karena nilai daktilitasnya kurang dari $50 \mathrm{~cm}$. Nilai daktilitas yang semakin rendah menunjukkan bahwa daya kohesi aspal semakin berkurang sehinnga tidak terlalu bagus dalam mengikat butir-butir agregat.

Hasil Uji Berat Jenis

Hasil pengujian berat jenis dapat dilihat pada Gambar 6.

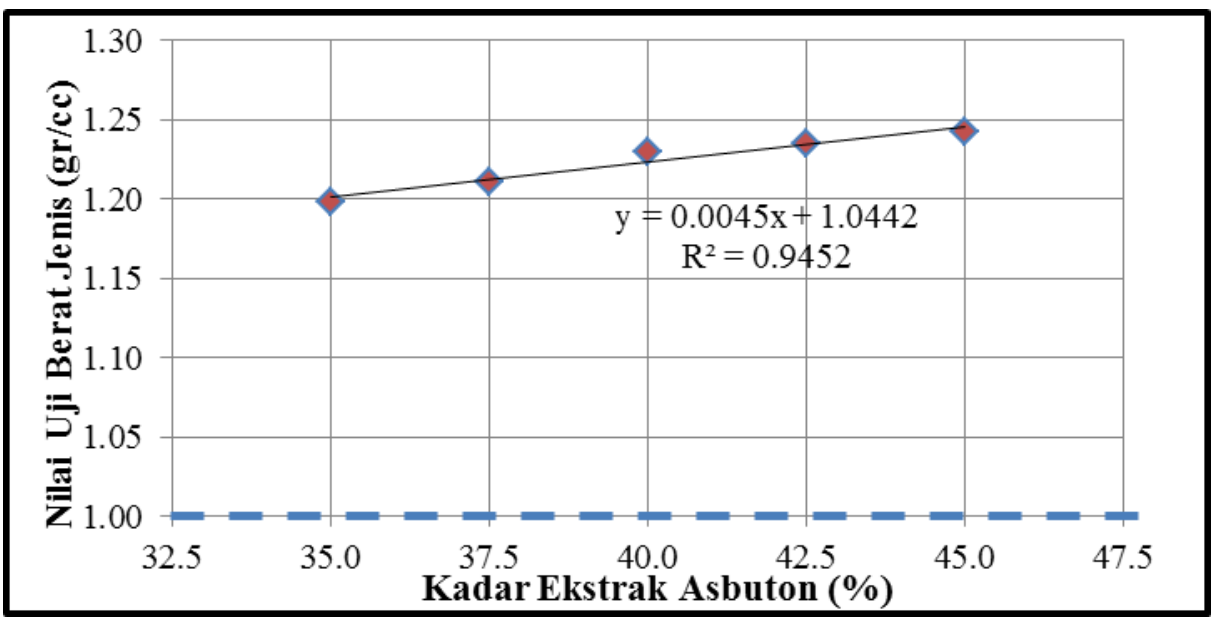

Persyaratan $=1$ gr/cc, Sumber : Pedoman Konstruksi dan Bangunan, No: 001-01/BM/2006, Pemanfaatan Asbuton, Departemen Pekerjaan Umum, Direktorat Jendral Bina Marga 
Gambar 6. Grafik hasil uji berat jenis variasi Semarbut Aspal Tipe 4

Gambar 6 menunjukkan bahwa penambahan kadar ekstrak asbuton pada Semarbut Aspal Tipe 4 membuat nilai uji berat jenis semakin naik. Sisi positif yang dapat diambil dari nilai berat jenis yang tinggi adalah perhitungan volume yang dibutuhkan semakin sedikit saat proses pengiriman dengan catatan suhu tetap terjaga. Dengan informasi berat jenis dan temperatur perhitungan volume yang didapatkan akan semakin akurat.

\section{Hasil Uji Kelekatan terhadap Agregat}

Modifikasi ekstrak asbuton dengan aspal penetrasi 60/70 memiliki sifat adhesi aspal sangat baik, hal ini dapat dilihat dari pengamatan visual terhadap benda uji yang menunjukkan bahwa aspal modifikasi masih dapat 100\% menyelimuti agregat dengan baik. Sehingga modifikasi aspal penetrasi 60/70 dengan ekstrak asbuton memiliki daya lekat yang sangat baik sebagai binder.

\section{Hasil Uji Kadar Kelarutan Aspal Variasi Komposisi Semarbut Aspal Tipe 4}

Uji kelarutan aspal modifikasi adalah pengujian untuk mengetahui persentase kadar aspal modifikasi yang dapat terlarut dalam Trichloroethylene teknis (TCE). Pengujian ini mengacu pada SNI 2438:2015. Rekapitulasi perhitungan kadar kelarutan aspal dari semua variasi komposisi Semarbut Aspal Tipe 4 disajikan pada Tabel 6 dan grafik hubungan penambahan kadar ekstrak asbuton terhadap kadar kelarutan aspal dapat dilihat pada Gambar 7.

Tabel 6. Rekapitulasi kadar kelarutan aspal variasi komposisi Semarbut Aspal Tipe 4

\begin{tabular}{llllll}
\hline \multirow{2}{*}{ No } & $\begin{array}{l}\text { Kadar } \\
\text { ekstrak } \\
\text { asbuton }\end{array}$ & Berat aspal & Berat filler & $\begin{array}{l}\text { Kadar yang tidak } \\
\text { larut TCE }\end{array}$ & $\begin{array}{l}\text { Kadar yang } \\
\text { larut TCE }\end{array}$ \\
\cline { 3 - 6 } & $\mathbf{( \% )}$ & $\mathbf{( g r )}$ & $\mathbf{( g r )}$ & $\mathbf{( \% )}$ & $\mathbf{( \% )}$ \\
\hline $\mathbf{A}$ & $\mathbf{B}$ & $\mathbf{C}$ & $\mathbf{d}$ & $\mathbf{e}=\frac{\mathbf{d}}{\boldsymbol{c}} \times \mathbf{1 0 0} \%$ & $\mathbf{f}=\mathbf{1 0 0 \%}-\mathbf{e}$ \\
\hline 1 & 35,0 & 2,13 & 0,08 & 3,76 & 96,24 \\
\hline 2 & 37,5 & 2,38 & 0,12 & 5,04 & 94,96 \\
\hline 3 & 40,0 & 2,24 & 0,11 & 4,91 & 95,09 \\
\hline 4 & 42,5 & 2,23 & 0,15 & 6,73 & 93,27 \\
\hline 5 & 45,0 & 2,08 & 0,15 & 7,21 & 92,79 \\
\hline
\end{tabular}

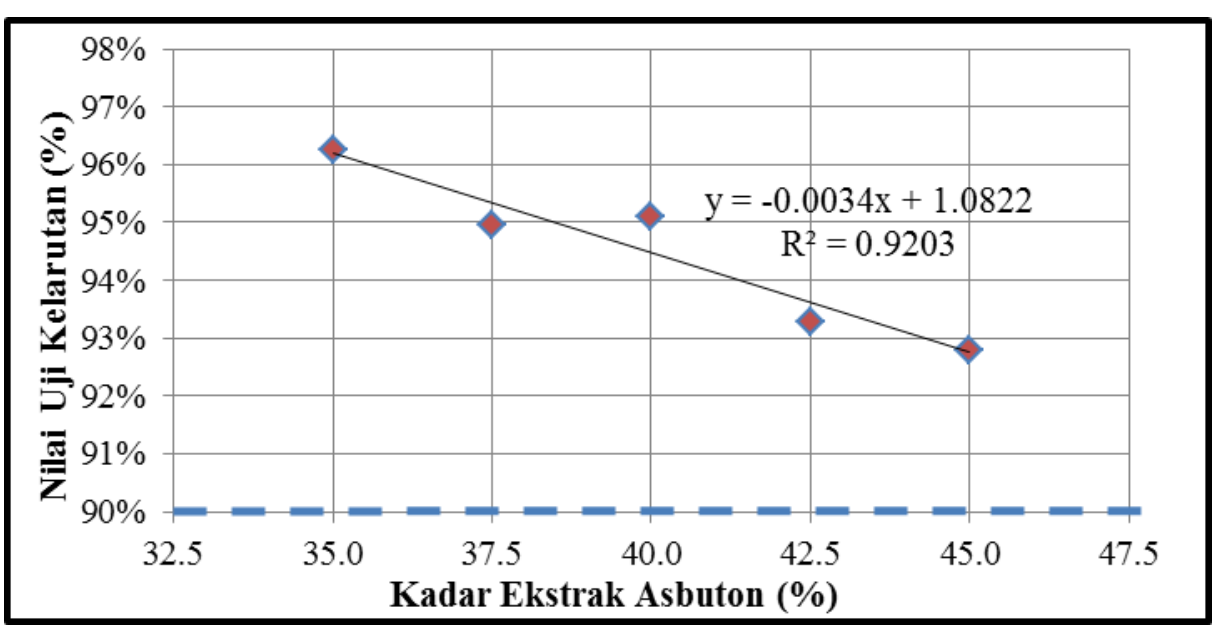

Gambar 7. Grafik hasil uji kadar kelarutan aspal variasi Semarbut Aspal Tipe 4

Gambar 7 menunjukkan bahwa penambahan kadar ekstrak asbuton pada Semarbut Aspal Tipe 4 membuat kadar kelarutan aspal semakin turun. Sesuai fungsi dari grafik yaitu y $=-0,0034 \mathrm{x}+1,0822$ bahwa penambahan kadar ekstrak asbuton berkorelasi negatif dengan kadar kelarutan, semakin banyak kadar ekstrak asbuton semakin rendah kadar kelarutan yang dihasilkan. Nilai $\mathrm{R}^{2}=0,9203$ pada grafik menunjukkan bahwa sebaran data sebesar 
92,03\% menyatakan nilai kadar kelarutan aspal dipengeruhi oleh kadar ekstrak asbuton dan sisanya dipengaruhi veriabel lain.

Indeks Penetrasi Variasi Komposisi Semarbut Aspal Tipe 4

Nilai Indeks Penetrasi (IP) diperoleh dari sifat-sifat fisik aspal yaitu titik lembek dan nilai penetrasi yang menggambarkan tingkat kepekaan aspal terhadap perubahan temperatur, semakin tinggi nilai penetrasi dan titik lembek maka semakin tinggi pula nilai IP-nya. Perhitungan indeks penetrasi dari semua variasi komposisi Semarbut Aspal Tipe 4 disajikan pada Tabel 7 dan grafik hubungan penambahan kadar ekstrak asbuton terhadap indeks penetrasi dapat dilihat pada Gambar 8.

Tabel 7. Indeks penetrasi aspal variasi komposisi Semarbut Aspal Tipe 4

\begin{tabular}{llllll}
\hline No & $\begin{array}{l}\text { Kadar ekstrak asbuton } \\
(\mathbf{\%})\end{array}$ & $\begin{array}{l}\text { Nilai penetrasi } \\
(\mathbf{x} 10-\mathbf{~ m m})\end{array}$ & $\begin{array}{l}\text { Titik lembek } \\
(\mathbf{~} \mathbf{C})\end{array}$ & $\mathbf{A}$ & $\begin{array}{l}\text { Indeks } \\
\text { penetrasi }\end{array}$ \\
\hline 1 & 35,0 & 51,6 & 55,75 & 0,0387 & 0,2191 \\
\hline 2 & 37,5 & 46,7 & 54,75 & 0,0415 & $-0,2394$ \\
\hline 3 & 40,0 & 45,7 & 55,50 & 0,0408 & $-0,1250$ \\
\hline 4 & 42,5 & 43,1 & 55,75 & 0,0413 & $-0,2050$ \\
\hline 5 & 45,0 & 37,7 & 56,50 & 0,0421 & $-0,3411$ \\
\hline
\end{tabular}

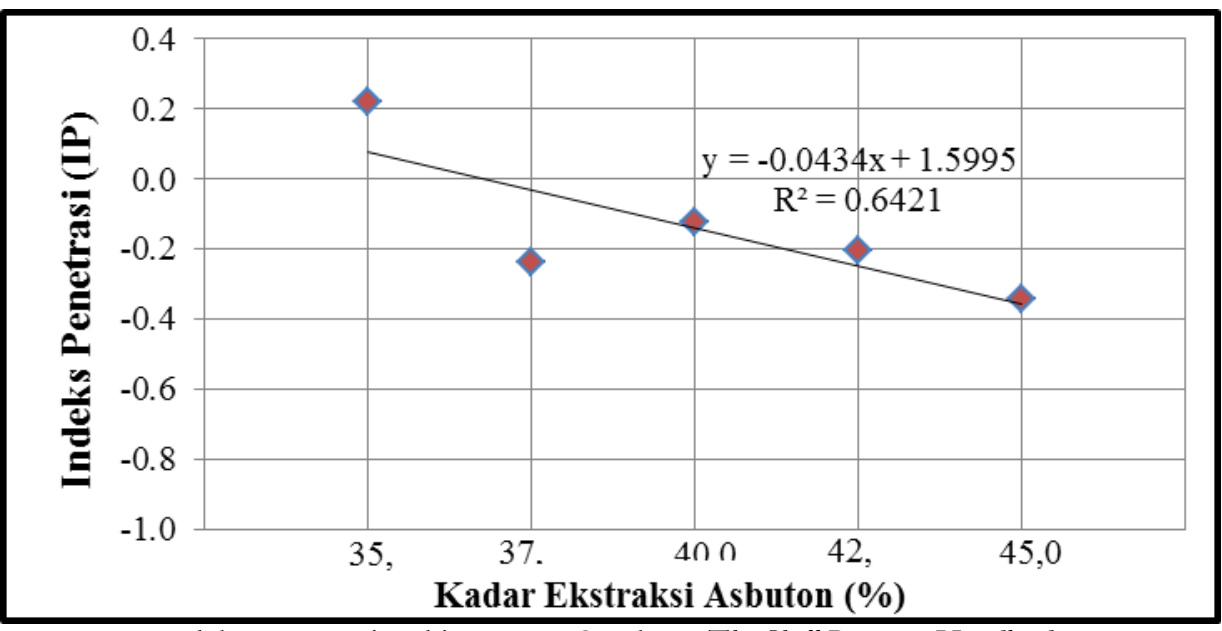

Persyaratan Indeks Penetrasi -3 hingga +7 , Sumber : The Shell Bitumen Handbook

Gambar 8. Grafik hubungan indeks penetrasi dengan penambahan kadar ekstrak asbuton

Grafik indeks penetrasi pada Gambar 8 menunjukkan bahwa penambahan ekstrak asbuton pada semarbut aspal sangat berpengaruh terhadap perubahan nilai Indeks Penetrasi. Nilai Indeks Penetrasi yang semakin turun seiring dengan penambahan ekstrak asbuton pada semarbut aspal, menunjukkan bahwa semarbut aspal akan semakin tidak tahan terhadap perubahan temperatur.

\section{Komposisi Semarbut Aspal Tipe 4 Optimum}

Berdasarkan hasil dari pengujian karakteristik aspal dan kadar kelarutan aspal dapat diketahui bahwa variasi komposisi semarbut dengan kadar ekstrak asbuton sebesar 35\% dan 40\% memenuhi semua spesifikasi nilai karakteristik aspal yang disyaratkan pada aspal yang dimodifikasi oleh asbuton, untuk kadar 37,5\% semua spesifikasi nilai karakteristik aspal memenuhi syarat kecuali nilai titik lembek, sedangkan untuk kadar 42,5\% dan $45 \%$ nilai daktilitas dan penetrasinya tidak memenuhi syarat. Diantara variasi semarbut dengan kadar ekstrak asbuton sebesar 35\% dan 40\% yang memenuhi semua spesifikasi nilai karakteristik aspal, maka dipilih satu komposisi optimum untuk Semarbut Aspal Tipe 4 yaitu kadar ekstrak asbuton sebesar $40 \%$ dan kadar aspal penetrasi $60 / 70$ sebesar $60 \%$, hal ini dikarenakan ekstrak asbuton yang digunakan lebih banyak sehingga pemanfaatan ekstrak asbuton lebih maksimal.

\section{SIMPULAN}


Hasil analisis uji kadar kelarutan ekstrak asbuton emulsi diperoleh waktu mixing asbuton dan solar selama 2 menit 50 detik menghasilkan kadar kelarutan ekstrak asbuton emulsi optimum sebesar 86,62\%. Nilai daktilitas ekstrak asbuton yang dihasilkan terlalu kecil, sehingga untuk memperbaikinya ditambahkan aspal penetrasi 60/70 menjadi Semarbut Aspal Tipe 4. Hasil pengujian karakteristik Semarbut Aspal Tipe 4 diperoleh komposisi optimum yaitu kadar ekstrak asbuton sebesar 40\% dan kadar aspal penetrasi 60/70 sebesar 60\%, komposisi ini memenuhi semua spesifikasi nilai karakteristik aspal yang dimodifikasi dengan asbuton, serta ekstrak asbuton yang digunakan lebih banyak sehingga pemanfaatan ekstrak asbuton lebih maksimal.

\section{SARAN}

Saran dari peneliti berdasarkan kendala yang dialami selama proses penelitian adalah:

1) Secara berkala melakukan pengecekan pada mesin ekstraksi asbuton sebelum digunakan dan jangan terlalu lama menggunakan mesin karena kecepatan mesin dapat menurun.

2) Waktu proses ekstraksi asbuton emulsi sebisa mungkin dibuat lebih singkat agar tidak terlalu lama dalam membuat ekstrak asbuton.

3) Selalu melakukan pengecekan kehilangan berat saat memanaskan ekstrak asbuton yang akan dibuat semarbut, karena apabila terlalu lama melakukan pemanasan akan mengeras dan tidak dapat digunakan.

\section{REFERENSI}

Kementrian Pekerjaan Umum. 1991. SNI 06-2432 tentang pengujian daktilitas aspal. Jakarta.

Kementrian Pekerjaan Umum. 1991. SNI 06-2433 tentang pengujian titik nyala, titik. bakar aspal. Jakarta.

Kementrian Pekerjaan Umum. 1991. SNI 06-2434 tentang pengujian titik lembek aspal. Jakarta.

Kementrian Pekerjaan Umum. 1991. SNI 06-2439 tentang pengujian kelekatan bitumen terbadap agregat. Jakarta.

Kementrian Pekerjaan Umum. 1991. SNI 06-2441 tentang aspal padat, Metode pengujian berat jenis. Jakarta.

Kementrian Pekerjaan Umum. 1991. SNI 06-2456 tentang pengujian penetrasi aspal. Jakarta.

Kementrian Pekerjaan Umum. 1991. SNI 06-2488 tentang pengujian berat jenis aspal. Jakarta.

Kementrian Pekerjaan Umum Ditjen Bina Marga. 2006. Pemanfaatan Asbuton. Pedoman No: 001-01/BM/ 2006.

Eka Nugraha, S. J., Sarwono, D., \& Setyawan, A. 2014. Kinerja Properti SEMARBUT Aspal Tipe I Penambahan Ekstraksi Asbuton Emulsi sebagai Modifikasi Bitumen).

Raharjo, P. S. 2016. Ekstraksi Asbuton Butir dengan Metode Asbuton Emulsi Ditinjau dari Waktu Mixing Fase Padat Menggunakan Emulgator Texapon dan Grinder Tipe Mb 60.

DARENDRA, R. S. 2016. Pengaruh Waktu Pemeraman Fase Padat Pada Asbuton Emulsi Terhadap Kadar Aspal Dengan Emulgator Texapon Menggunakan Grinder Tipe MB 60.

Wibowo, L. T. 2016. Karakteristik Penambahan Ekstraksi Asbuton Emulsi pada Aspal Penetrasi 60/70 Sebagai Modifikasi Bitumen (Semarbut Aspal Type 2). 